3 (2020) <DIGITÁLIS BÖLCSÉSZET>

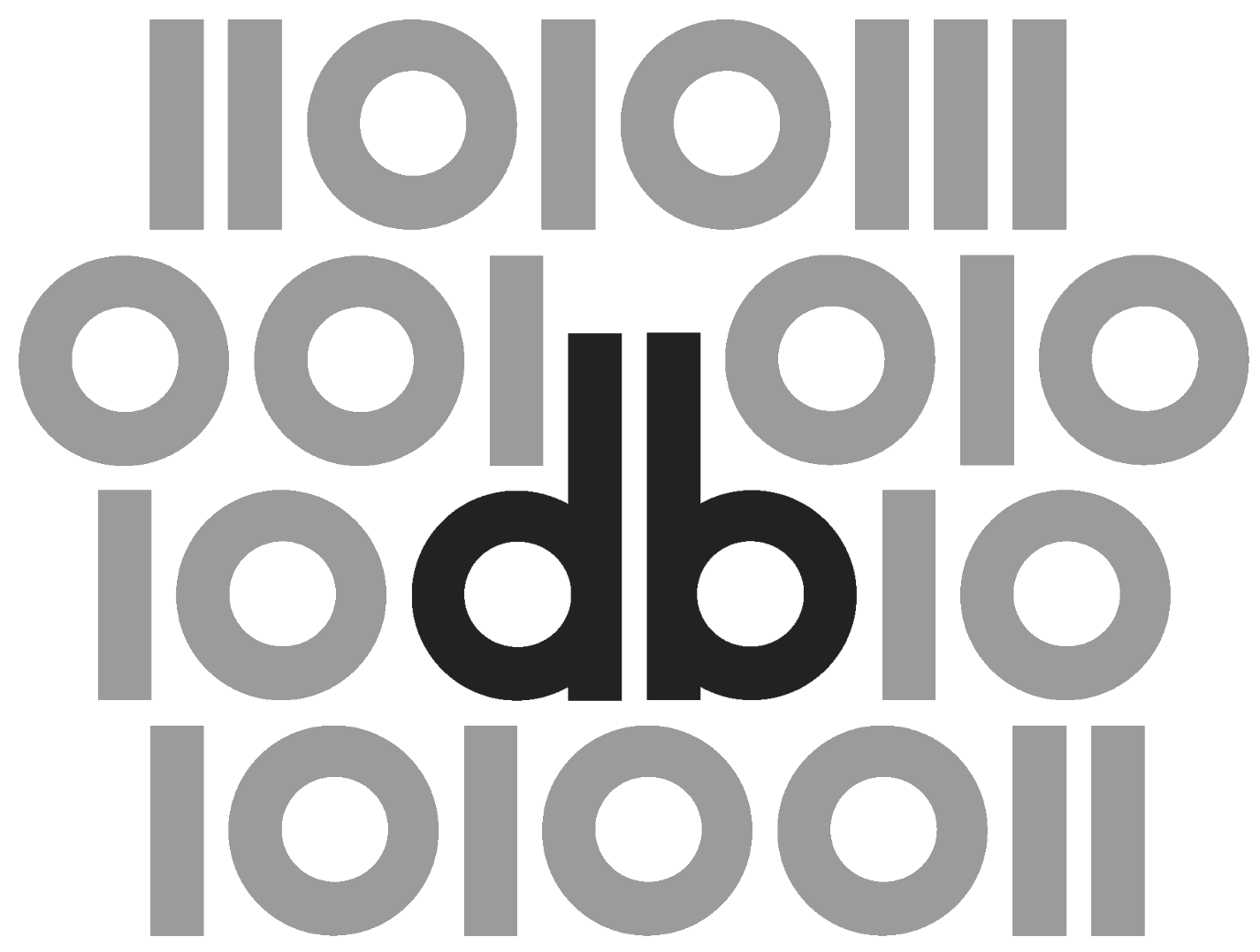

3 (2020) </DIGITÁLIS BÖLCSÉSZET> 
Digitális Bölcsészet 2020., harmadik szám 


\section{〈DIGITÁLIS BÖLCSÉSZET>}

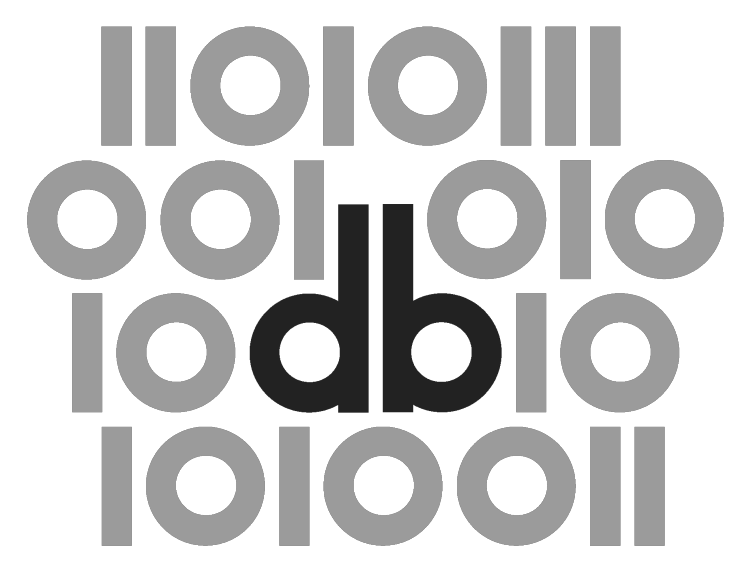

3(2020) 
Felelős szerkesztő:

Maróthy Szilvia

Szerkesztőség:

Kokas Károly, Parádi Andrea

Rovatvezetők:

Tanulmányok: Kiss Margit

Mühely: Péter Róbert

Kritika: Almási Zsolt

Labor: Maróthy Szilvia

Tanácsadó testület:

Bartók István, Fazekas István, Golden Dániel, Horváth Iván, Palkó Gábor, Pap Balázs, Sass Bálint, Seláf Levente

Korábbi munkatársaink:

Bartók Zsófia Ágnes (szerkesztő, rovatvezető), Fodor János (szerkesztő), †Labádi

Gergely (szerkesztő, rovatvezető), †Orlovszky Géza (tanácsadó testület)

\section{ISSN 2630-9696}

\section{DOI 10.31400/dh-hun.2020.3}

Kiadja a Bakonyi Géza Alapítvány és az ELTE BTK Régi Magyar

Irodalom Tanszéke (1088 Budapest, Múzeum krt. 4/A).

Felelős kiadó az ELTE BTK Régi Magyar Irodalom Tanszék vezetője.

Megjelenik az Open Journal Systems (OJS) v. 3. platformon, melynek működtetését az ELTE Egyetemi Könyvtár- és Levéltár biztosítja.

\section{$\Pi<a$}

Munkánkat a Nemzeti Kulturális Alap támogatja.

\section{(cc) BY-NC-SA}

Ez a mü a Creative Commons Nevezd meg! - Ne add el! - Így add tovább! 2.5 Magyarország Licenc (http://creativecommons . org/licenses/by-nc-sa/2.5/hu/) feltételeinek megfelelően felhasználható.

Honlap: http://ojs.elte.hu/digitalisbolcseszet

Email cím: dbfolyoirat@gmail.com

Olvasószerkesztő : Bucsics Katalin

Tördelés: Hegedüs Béla

Grafika: Hegyi Gábor 


<MÜHELY> 



\title{
Harangozó Ádám
}

független kutató

adamhrngzo@gmail.com

\section{FactGrid : adatbázis történészeknek}

\begin{abstract}
A FactGrid egy szabadon felhasználható adatokkal dolgozó, közösségi adatbázis történészeknek. A könnyen szerkeszthető, Wikibase alapú platformon a különböző kutatási projektek egy adatbázisban tárolhatnak és elemezhetnek strukturált adatokat. Az összekapcsolt adatok hosszútávon szerkeszthetőek maradnak, továbbá komplex lekérdezéseket végezhetünk rajtuk, áttekinthetünk hálózati kapcsolatokat, illetve megjeleníthetjük az adatokat térképen vagy idővonalon is. Tanulmányomban a platform bemutatásán túl azt igyekszem feltérképezni, mivel járulhat hozzá a hazai tudományhoz ez a szabadon felhasználható adatokkal dolgozó kezdeményezés.
\end{abstract}

Kulcsszavak:

adatbázis, FactGrid, Wikibase, strukturált adatok, összekapcsolt nyílt adatok, történettudomány

\section{Bevezetés}

Már magyarul is beszél a FactGrid, egy közösségi adatbázis történészeknek. ${ }^{1}$ A közösségi jelző semmiképp sem a szakértelem hiányát jelöli - az adatbázist kizárólag kutatók szerkeszthetik -, hanem a szemléletet. Tanulmányomban a platform bemutatásán túl azt igyekszem feltérképezni, mivel járulhat hozzá a hazai kutatásokhoz ez a szabadon felhasználható adatokkal dolgozó kezdeményezés.

A platform ötlete az Erfurti Egyetemen végzett kutatásból született, ${ }^{2}$ ahol a 18. századi Illuminátus-rend dokumentumaiból építettek adatbázist, feltérképezve a szervezet kapcsolati hálóját, szokásait, helyszíneit. Bár 2016-ban a projekt finanszírozása a Gotha Kutatóközpont által lezárult, egyre több, a témát kutató történész csatlakozott óriási adatgyűjtésekkel, az adatbázisszoftver és kiszolgálófelület pedig hamar elégtelennek bizonyult a növekvő felhasználói igényeknek. A komplex adatbázis követelményeinek jobban megfelelő, rugalmas, többnyelvü szoftvert keresve szövetkeztek a Wikimédia németországi szervezetével, hogy 2018-ban az általuk fejlesztett szoftverre építsék fel az új platformot, a FactGridet. Az új oldal már azzal a céllal készült, hogy egy általános nemzetközi adatbázis és kutatói környezet legyen történészek számára.

1 „FactGrid: Kezdőlap,” FactGrid, hozzáférés: 2020.06.12, https://database.factgrid.de/wiki/K ezdőlap.

2 „FactGrid: Gotha Illuminati Research Base Team,” FactGrid, hozzáférés: 2020.06.12, https ://datab ase.factgrid.de/wiki/FactGrid:Gotha_Illuminati_Research_Base_Team. 


\section{Wikibase, Wikidata, FactGrid}

A platform lelke a nyílt forráskódú Wikibase. ${ }^{3}$ Ezt a szoftvert a Wikimédia fejlesztette a Wikidata ${ }^{4}$ számára, amely strukturált, központi adatbázisként szolgál a világ összes Wikipédiájának, ezen felül pedig bárki szabadon használhatja. A Wikidata segítségével a Wikipédián egy téma bármely nyelven íródott szócikke egyazon elemre mutat az adatbázisban. ${ }^{5}$ Ezek az elemek nemcsak a különféle nyelvi verziókat kötik össze, de egy nagy ívű ontológiában ${ }^{6}$ kapcsolódnak egymáshoz, amely a Wikipédiát is segít strukturálni.

Mielőtt rátérünk a FactGrid működésére, fontos leszögezni, hogy a történészi platform és a Wikidata nem vetélytársak vagy alternatívák, hanem egymást kiegészítő rendszerek. A Wikidata hasznosságát egyre több intézmény fedezi fel, és vannak kutatások, amelyek számára tökéletes otthont nyújt, ${ }^{7}$ de az oldal két alapvető irányelve a legtöbb kutatási projektet kizárja. Ezek egyike a nevezetesség elve, ${ }^{8}$ amely bár kevésbé szigorúan, mint a Wikipédián, de megköveteli, hogy minden létrehozott adatbáziselem valamiféle relevanciával rendelkezzen, például azáltal, hogy több egymástól független forrás is említi. A másik irányelv szerint a Wikidata nem adhat helyet saját kutatásunk első közlésének. ${ }^{9}$ Ezek a Wikidata szempontjából nagyon is helyes elvek nem teszik lehetővé, hogy például komplett történelmi adathalmazokat töltsünk fel, tele eddig ismeretlen vagy akár azonosítatlan személyekkel.

Ezt a hiányt pótlandó, a FactGrid kiválóan használható nemcsak mint hosszútávú tárhely, hanem mint munkafelület, adatok elemzéséhez, vizualizációjához. Bármilyen új vagy már lezárult kutatás során keletkezett adathalmazt feltölthetünk, legyen az egy történeti címjegyzék összes személye, folyóiratok előfizetői, klubok tagjai és így tovább.

3 A szoftver bemutatását lásd: „Wikibase, hozzáférés: 2020.06.12, https://wikiba.se/.

4 Wikidata, „Wikidata: Kezdőlap, hozzáférés: 2020.06.12, https ://www.wikidata.org/wiki/Wik idata:Kezdőlap.

5 Például: Wikidata, „Hunyadi János (Q242688),” hozzáférés: 2020.06.12, https : / www . wikidata.or $\mathrm{g} /$ wiki/Q242688.

6 Wikidata, „Wikidata Generic Tree,” hozzáférés: 2020.06.12, https : //wikidata-todo.toolforge . org/tree.html?q=Q35120\&rp=279\&lang=en\&method=list\&depth=2.

7 Ilyen például a COURAGE-projekt (Kulturális ellenállás. Az ellenzékiség öröksége az egykori szocialista országokban), hozzáférés: 2020.06.12, http://hu.cultural-opposition.eu/registr y/. Erről bővebben lásd: Ghazal Faraj and András Micsik, „Enriching Wikidata with Cultural Heritage Data from the COURAGE Project," Emmanouel Garoufallou, Francesca Fallucchi and Ernesto William De Luca, eds., Metadata and Semantic Research: 13th International Conference, MTSR 2019, Rome, Italy, October 28-31, 2019, Revised Selected Papers, Communications in Computer and Information Science book series 1057 (Cham: Springer, 2019), 407-418, https://doi .org/10.10 07/978-3-030-36599-8_37.

8 „Wikipédia: Nevezetesség," Wikipédia, hozzáférés: 2020.06.12, https://hu.wikipedia.org/wik i/Wikipédia: Nevezetesség.

9 „Wikipédia: A Wikipédia nem az első közlés helye," Wikipédia, hozzáférés: 2020.06.12, https://h u.wikipedia.org/wiki/Wikipédia:A_Wikipédia_nem_az_első_közlés_helye. 


\section{Hogyan müködik?}

Az adatbázis felülete könnyen átlátható, egyszerűen szerkeszthető. Minimális programozói tudásra csak a lekérdezéseknél lehet szükségünk (SPARQL), de ehhez is rendelkezésünkre állnak vizuális alternatívák.

Ahogy minden Wikibase alapú adatbázis, a FactGrid is egyedi azonosítóval, Qszámmal ellátott elemekből áll, azaz Q147798 = Johann Sebastian Bach. A numerikus azonosító mellett minden elem címkékkel rendelkezik, amelyeket bármilyen nyelven megadhatunk, illetve az ezekhez külön-külön kapcsolódó leírásokkal is. Fontos megjegyezni, hogy a FactGrid (és a Wikidata) Q-számai nemcsak egyedi, de állandó azonosítók is. Sosem kerülnek újrafelhasználásra, duplikált elemek összevonása után pedig a kiürített azonosító átirányító oldalként funkciónál azon elem felé, amelyben összevonásra került, tehát a régi elemre mutató külső linkek sem évülnek el.

Az elemeket állításokkal írhatjuk le, amelyek tulajdonságok és értékek párosából állnak. A tulajdonságok egy saját számrendszerben mozognak „P” előjellel, a hozzájuk kapcsolt érték pedig leggyakrabban szintén egy adatbáziselem (Q), de lehet egyszerü szöveg, link vagy médiafájl is. Vagyis: Johann Sebastian Bach (Q147798) gyermeke (P150) Johann Christian Bach (Q147795). Egy tulajdonság több értékkel is rendelkezhet, esetünkben, mivel népes a Bach család: Johann Sebastian Bach (Q147798) gyermekei (P150) Carl Philipp Emanuel Bach (Q165366), Wilhelm Friedemann Bach (Q165365), Johann Christian Bach (Q147795), stb. A numerikus azonosítókat nem szükséges fejből tudnunk, elég elkezdeni begépelni az adott címkét a saját nyelvünkön, és a rendszer felajánlja a megfelelő elemet. Minden elem nagyobb kategóriákba sorolódik (Prága $\rightarrow$ város $\rightarrow$ közigazgatási egység), ahogy a tulajdonságok is (feleség $\rightarrow$ házastárs $\rightarrow$ családi kapcsolatok $\rightarrow$ emberi kapcsolatok $\rightarrow$ elemek közötti kapcsolatok).

A P-számok egy csoportja minősítőként használható, tehát állításokat pontosíthatunk, árnyalhatunk velük. Rákosi Mátyás (Q165367) házastársa (P84) Feodora Fjodorovna Kornyilova (Q165368) + házasság kezdete (P49) 1942 (dátum).

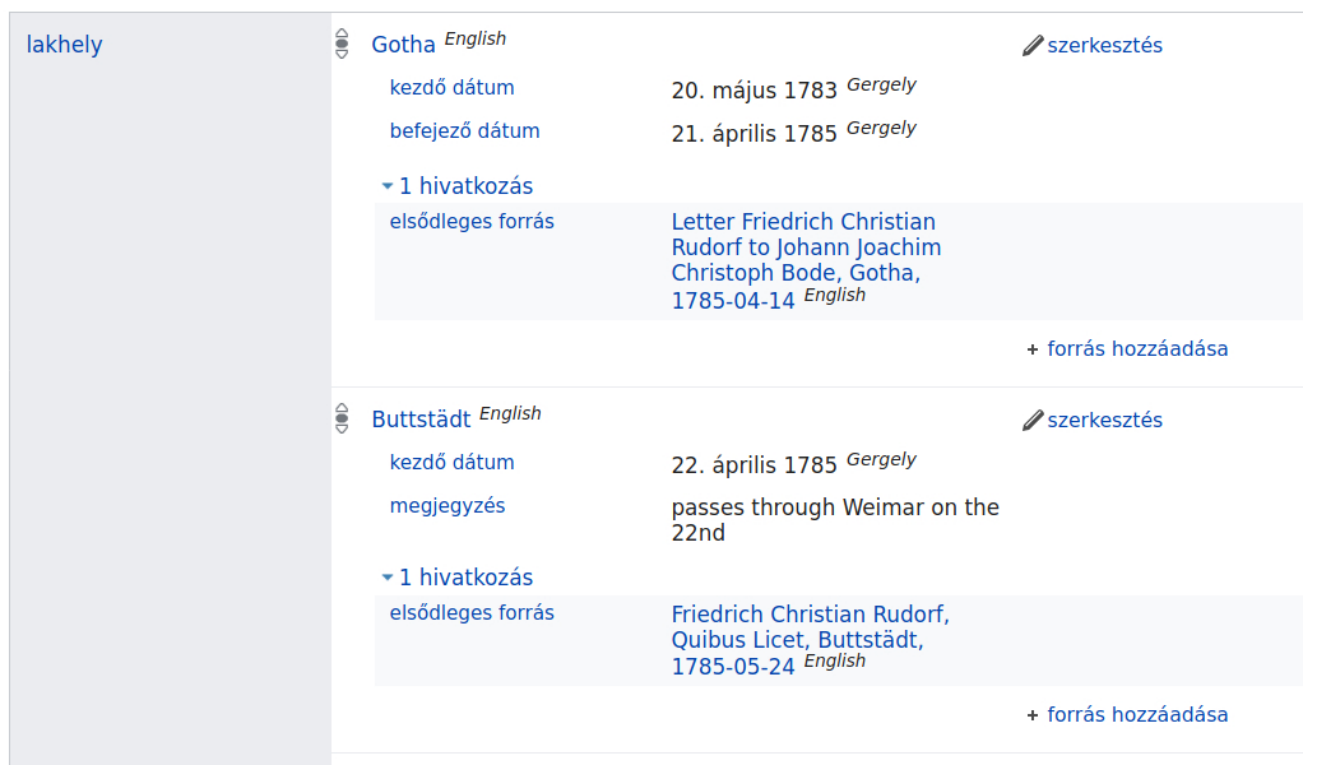

1. ábra. Friedrich Christian Rudorf adatlapja (részlet) 
Minden egyes állítást alátámaszthatunk forrásokkal, akár többel is. A FactGriden megadhatunk egymással versengő információkat is, mindegyiket saját hivatkozásokkal, például ha esemény időpontja különböző forrásokban eltérő dátumok alatt szerepel. Ezt nemcsak akkor tehetjük meg, ha nem tudjuk, melyik áll közelebb az igazsághoz, hanem akkor is, ha szeretnénk felsorolni a különböző variánsokat, modellezni egy történeti vitát vagy jelezni szeretnénk egy gyakran előforduló tévedést. A különböző információkat egyszerủen rangsorolhatjuk, kiemelhetjük az aktuálisan elfogadott értéket, illetve minősítőkkel jelezhetjük a megbízhatóságukat. Ez a rugalmasság annak is teret enged, hogy létrehozzunk új elemeket vagy elemek közötti kapcsolatokat pusztán kísérleti célból, például egy feltevés vagy munkahipotézis teszteléséhez. ${ }^{10}$

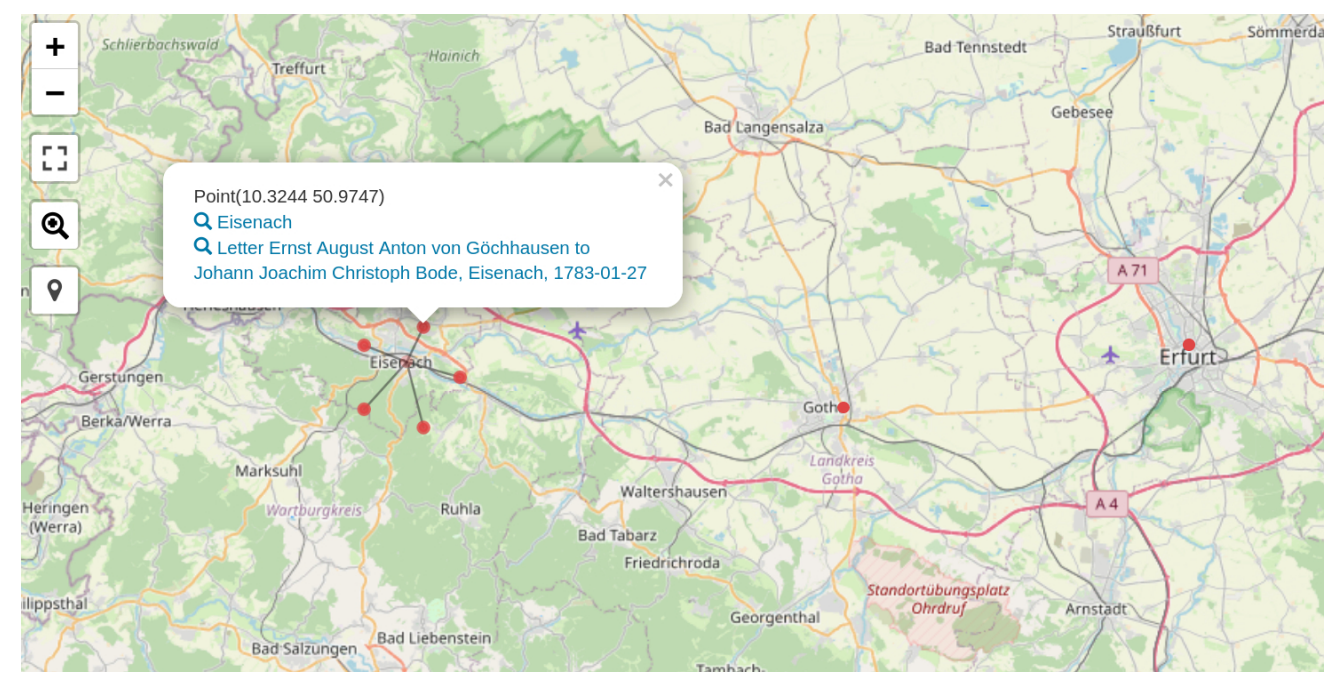

2. ábra. Illuminátus-dokumentumok származási helyei térképre vetítve

Az FactGrid-elemeket a belső kapcsolatokon felül külső adatbázisokhoz is hozzákapcsolhatjuk. Bachnál például megadhatjuk, milyen azonosítóval szerepel a GNDben, a Nemzeti Névtérben, a VIAF-ban, a Bach Digital-projektben, illetve bármilyen egyéb oldalon, katalógusban, amelyekre szükségünk van a kutatásunkhoz. Ugyanígy tulajdonságokat is megfeleltethetünk más ontológiákban elfoglalt helyüknek, ezáltal „hozzátérképezhetjük” az adatmodellünket másokéhoz. Külső adatbázisok vissza is utalhatnak a FactGridre, a Wikidatára például már több könyvtári és múzeumi katalógus, köztük a VIAF ${ }^{11}$ és a MoMa ${ }^{12}$ is hivatkozik. Bár még nem alakult ki gyakorlata, a releváns Q-számokat elhelyezhetjük cikkekben, tanulmányokban, akár blogbejegyzésekben is, illetve bárhol hivatkozhatunk velük például a projektünk során létrehozott adatkészletre.

10 A működési elvek itteninél részletesebb kifejtése a projekt blogján magyarul is olvasható, illetve egy kis kalandozással az oldalon vagy a Wikidatán könnyű és élmény kiismerni azokat. Lásd Olaf Simons, „FactGrid GYIK - Miért használjam a FactGridet a kutatási projektemhez?, https : //blo g.factgrid.de/archives/1955.

11 Például VIAF, „Arany János (95251869),” hozzáférés : 2020.06.12, https : //viaf .org/viaf /95251 869/.

12 Például MoMa, „Marina Abramović (26439), hozzáférés: 2020.06.12, https : / www .moma.org/art ists/26439. 
Az adatbázisra egy hagyományos Wikipédia-külsejü (MediaWiki) réteg is került, annak minden funkciójával. Itt szabadon létrehozhatunk az adatainkkal összekapcsolt „szócikkeket”, ahol közölhetünk szövegeket, átiratokat vagy készíthetünk külön oldalt projektünknek, ahol a kutatócsoport koordinációját végezhetjük. ${ }^{13}$

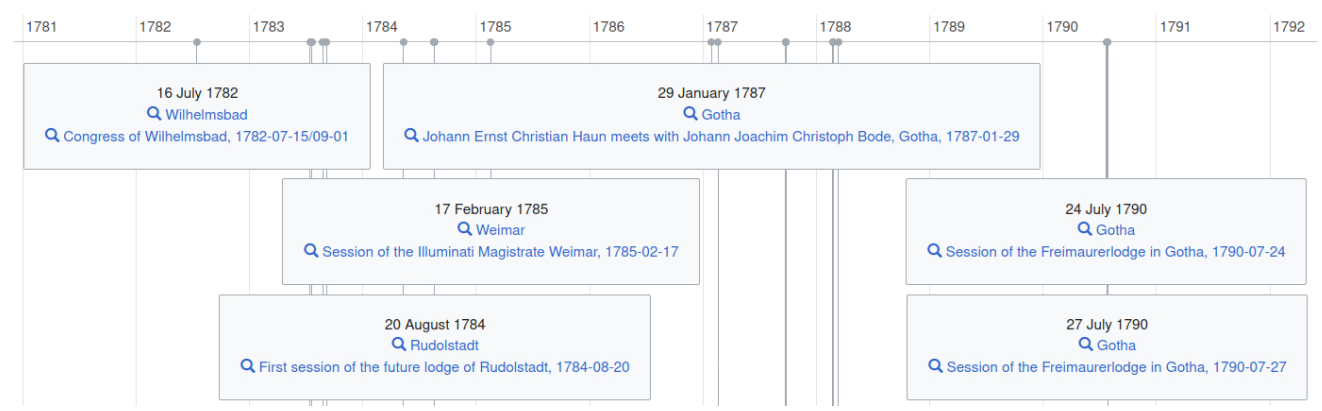

3. ábra. Idővonal: események, amelyeken J. J. C. Bode részt vett

\section{Bábeli rend}

A FactGrid egyik alapvető funkciója, hogy bármilyen nyelven „írhatjuk”, a felhasználó pedig saját nyelvén olvashatja: tehát nemzetközi. Mivel a rendszer maga csak Qszámokkal dolgozik, ezért amikor megadjuk például a Bach-foglalkozása-zeneszerző hármast saját nyelvünkön, a többi felhasználó ugyanazokat a Q- és P-számokat látja, mindössze saját nyelvén felcímkézve. Ezáltal, ha a világ másik pontján javítanak, bővítenek egy számunkra fontos adaton, az egyből felhasználhatóvá válik anyanyelvünkön is. A nyelvi korlátok nélküli szabadság a FactGrid segédeszközeivel készíthető vizualizációkban, idővonalakon, térképeken is megjelenik. Ehhez a többnyelvűséghez viszont szükséges, hogy az elemek címkéi létezzenek az adott nyelven. A mindenki számára nyitott és egyszerü fordítási folyamatot is felgyorsítja a közösségi szerkesztés, minél több a felhasználó, annál jobban.

Az oldalon található projektek többsége egyelőre nem kifejezetten kutatás, inkább előzetes adatbázis-építés és a platform nyújtotta lehetőségekkel való kísérletezés. Egyikük például a Szász-Gotha-Altenburg Hercegség területén lévő plébániák és lelkészek hálózatát térképezi fel 1500 és 1920 között. ${ }^{14}$ A későbbi kutatás megalapozásához a Thüringer Pfarrerbuch-sorozat első kötetét ${ }^{15}$ alakították FactGrid-adatokká: a könyv felsorolja a Hercegség összes lelkészét és a plébániák egyéb dolgozóit, illetve életrajzaikat, leszármazásukat. A legnagyobb kihívást az jelentette, hogy minden személy saját, külön azonosítót kapjon, mivel a nevek gyakran öröklődtek családon belül,

13 Például „FactGrid: The Global Genealogy of Lodges,” FactGrid, hozzáférés: 2020.06.12, https ://d atabase.factgrid.de/wiki/FactGrid:The_Global_Genealogy_of_Lodges.

14 „FactGrid: Religion im Herzogtum Gotha-Sachsen-Altenburg," FactGrid, hozzáférés: 2020.06.12, ht tps://database.factgrid.de/wiki/FactGrid:Religion_im_Herzogtum_Gotha-Sachsen-Altenburg.

15 Bernhard Möller, hrsg., Thüringer Pfarrerbuch. Band. 1: Herzogtum Gotha. Schriftenreihe der Stiftung Stoye der Arbeitsgemeinschaft für Mitteldeutsche Familienforschung e.V, Band 26 (Neustadt an der Aisch: Verlag Degener \& Co., 1995). 
és a kötetben szereplő életrajzok nem egyértelműsítik, pontosan kire utalnak. A duplikátumok nagy részét más forrásokkal összevetve sikerült kiküszöbölni, így jelenleg 13344 személyből áll az adathalmaz, részletes állításokkal azok családi kapcsolatairól, a plébániákban betöltött szerepeikről és ezek időpontjairól. A lelkészi családfák és plébániák térképre vetítésével az adatbázis lehetővé teszi, hogy a kutatók olyan kérdéseket vizsgálhassanak, mint hogy milyen előnyökkel szolgálhattak a házasságkötések a karrier szempontjából, hogyan változott az idők során a családi befolyás a gyermekek egyházi pályaválasztására, vagy mennyiben nőtt túl a helyi lelkészhálózatokon az egyházi kinevezettek földrajzi elhelyezkedése. A projekt egyik további célkitűzése annak vizsgálata, hogyan lehetne használni a FactGridet a könyvsorozat jövőbeni köteteinek előkészítéséhez. ${ }^{16}$

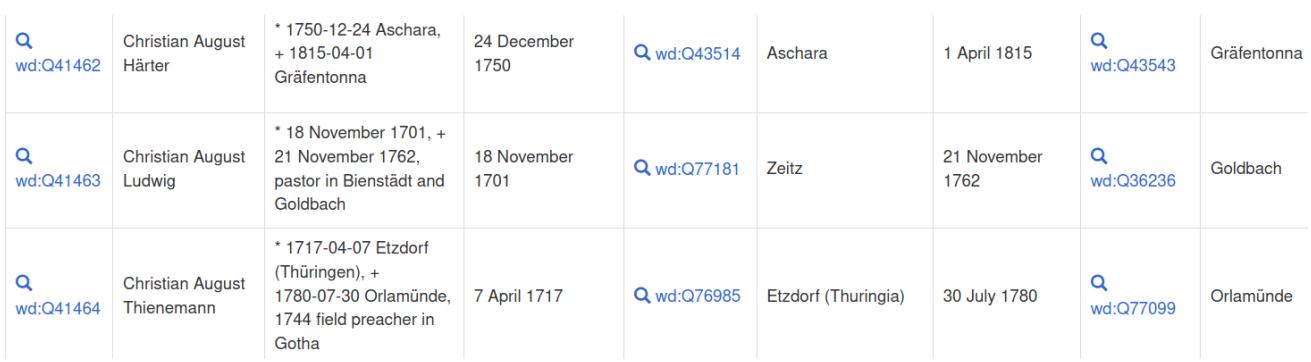

4. ábra. A Thüringer Pfarrerbuch adatbázisként: személyek, születési és halálozási helyek, idők

Az első nemzetközi kutatás a FactGriden a korai gyarmati Mexikóval foglalkozik. A Lancesteri Egyetem digitális bölcsészeti központja, a mexikóvárosi Templo Mayor Múzeum és a Lisszaboni Egyetem számítógép-tudományi kutatóközpontja az ÚjSpanyolországból küldött jelentéseket veti alá számítógépes elemzésnek, azt kutatva, hogyan jellemezték a spanyol gyarmatosítók az őslakosokat és földjeiket, illetve hogyan használták ezeket az információkat saját céljaikra. ${ }^{17}$

Fontos megjegyezni, hogy a FactGridnek, bár egyre többen használják, még vannak hiányosságai. A fordítás még csak kevés nyelven megkezdett, magyarul közel sem teljes, illetve az oldal egyelőre nem rendelkezik alapos útmutatókkal. Az adatmodell sem mindenre kiterjedő, például továbbra is kérdéses, külön elemekként vagy egy folytonosságként szerepeljenek a bezárt majd újraindított intézmények. Mindenesetre a közösségi modell miatt a rendszer fejlesztésére irányuló kezdeményezések könnyebben lendületet kaphatnak, és ebben minden felhasználó részt vehet, jelentse ez egy-egy címke lefordítását vagy új funkciók fejlesztését.

\section{Az adat mint közkincs}

A mind jobban neoliberális, piaci keretbe szorított egyetemek oktatóin folyamatos a nyomás, hogy minél többet publikáljanak, másszák a ranglétrát, hogy minden kutatás

16 Olaf Simons, „The First Volume of the Thuringian Pastor's Book (1500-1920) as a Wikibase Data Set,” https://blog.factgrid.de/archives/1941.

17 „FactGrid: Digging into Early Colonial Mexico," FactGrid, hozzáférés: 2020.06.12, https ://datab ase.factgrid.de/wiki/FactGrid:Digging_into_Early_Colonial_Mexico. 
sikerrel, hasznosítható eredménnyel záruljon. Mivel a legtöbb - ha nem minden kutató ebben a tudástermelési rendszerben kényszerül dolgozni, joggal merülhet fel a kérdés : miért ossza meg a kutató közkincsként a komoly erőfeszítések árán kibányászott adathalmazokat? A FactGrid használatával azonban nem veszik el a kutatói én.

Minden FactGrid-adat $\mathrm{CC} 0$-licenccel ${ }^{18}$ rendelkezik, más szóval kutatásunk közkincsként lesz elérhető és szabadon felhasználható. A CC0 nem kötelez forrásmegjelölésre, ez azonban nem jelenti azt, hogy a felhasználók nem is fognak majd hivatkozni a szerzőre. A FactGrid (és a legtöbb nyílt licencű projekt) kifejezetten ösztönzi a felhasznált adatok forrásmegjelölését, mindössze nem jogi ostorral, hanem kommunikációval és a szerzőiség átláthatóságával. A FactGriden minden egyes szerkesztés, legyen az egy apró korrekció vagy ezernyi új adat, a felhasználó saját fiókjához kapcsolódik, tehát bármit is csinálunk, az automatikusan az aláírásunkkal rendelkezik. Bizonyítani sem körülményes, hisz szerkesztési történetünk mindenki számára nyilvános.

Ellenben, ha kifejezetten hangsúlyozni szeretnénk factgrides munkásságunkat, létrehozhatunk olyan gyűjtőoldalakat is, amelyek az összes szerkesztésünket tartalmazzák, ${ }^{19}$ illetve saját adatalteregónk is részletes önéletrajzként szolgálhat. ${ }^{20}$ A szerkesztési összefoglalókat felhasználhatjuk a projekt beszámolójában, szakmai önéletrajzunkban vagy akár afféle minitanulmányként is. Nemcsak hogy szerzői leszünk adatainknak és modelljeinknek, de ezek, jogi korlátozások nélkül, könnyen túlszárnyalhatják saját projektünket, és más kutatások, publikációk számára is értékes forrássá válhatnak, mindvégig a saját nevünk alatt. Bár adatbázisok esetén nagy számokról beszélünk, a közösségi szerkeszthetőség révén egy módosítás, egy új tulajdonság vagy kapcsolat is jelentős változást hozhat.

Az átláthatóság és a széles körű szerkeszthetőség az elévülés legjobb ellenszere is. Az internetes közlés régóta ismert előnye a nyomtatott betű rögzítettségével szemben, hogy online utólag is javíthatjuk, bővíthetjük munkánkat. Ugyanakkor, ha egy projekt már rég lezárult, nem finanszírozott, nem profitál, gyakran nincs lehetőségünk a hibák javítására vagy frissíteni új eredményekkel, talán még szerkesztői hozzáférésünk sincs. Ha adatainkat egy nyílt rendszerbe visszük fel, nemcsak általunk lesznek javíthatóak, hanem amikor mi már egyéb projektekkel foglalkozunk, mások is frissíthetik őket. Így például nem történhet meg, hogy néhány elkövetett hiba vagy részbeni elévülés miatt kutatásunk elfelejtődik.

A FactGrid, bár ugyanúgy hasznos és működőképes a teljesítmény alapú, a metrika bűvöletében felgyorsuló egyetemi rendszerben, igazából egy értékeken nyugvó, emberközpontú, lassú ${ }^{21}$ tudomány keretein belül értelmezhető. Egyszerre lehet modern, nemzetközi szinten felmutatható eszköz a humántudományok elértéktelenődésével

18 „CC0," Creative Commons, hozzáférés: 2020.06.12, https ://creativecommons . org/share-you $\mathrm{r}$-work/public-domain/cc0/.

19 Mivel lekövethető minden változás szerzője, időpontja és tartalma, akár meta-történetírásként, historiográfiaként is tekinthetünk rá.

20 Például FactGrid, „Olaf Simons (Q11298), hozzáférés: 2020.06.12, https : / database.factgrid.d e/wiki/Item:Q11298.

21 Alison Mountz, Anne Bonds, Becky Mansfield, Jenna Loyd, Jennifer Hyndman, Margaret WaltonRoberts, Ranu Basu, Risa Whitson, Roberta Hawkins, Trina Hamilton and Winifred Curran, „For Slow Scholarship: A Feminist Politics of Resistance through Collective Action in the Neoliberal 
szemben, és strukturális elmozdulás a nyílt tudomány felé. Higgadt, mégis radikális kezdeményezés a digitális humanizmus bécsi kiáltványa ${ }^{22}$ sőt a barlowi függetlenségi nyilatkozat ${ }^{23}$ szellemében. Használata lehetőséget nyújt tapasztalt kutatók számára, hogy reflektálhassanak a jelenlegi rendszerre és abban elfoglalt helyükre, illetve egyetemi hallgatóknak, hogy egy átlátható, nem tekintélyelvű rendszerben válhassanak kutatókká.

\section{A Wiki-galaxis felé}

Miközben az egyetemi folklór része a Wikipédia-használat tiltottsága, ${ }^{24}$ egyre több oktató fedezi fel, hogy az oldal irányelvei valójában igen hasonlóak a tudományos szövegek követelményeihez, sőt a Wikipédia-szerkesztés fejleszti a hallgatók írásés kutatási készségeit. ${ }^{25}$ Emiatt számos egyetem kezdte beemelni a tananyagba a Wikipédia-szerkesztést, például szemináriumi feladatok szintjén. ${ }^{26}$

Ennek mintájára megfontolandó a FactGrid alkalmazása az egyetemi oktatásban is: használatával a diákok a jövőben elengedhetetlen digitális bölcsészeti szoftvereket tanulhatnak meg kezelni, köztük a Wikipédiát működtető MediaWikit is, és elsajátíthatják a közösségi munkát, illetve azt a szemléletet, amely a tudást és a kultúrát közkincsnek tekinti. Mindeközben pedig változatlanul tudományos környezetben maradnak.

A FactGrid kiváló lehetőség, hogy az oktatók együtt dolgozhassanak a hallgatókkal, méghozzá nem egy szimulált, ingerszegény, hanem egy olyan környezetben, ahol, jobb esetben, a tanár maga is dolgozik. Így a diákok korán bevonódhatnak a kutatói munkába, méghozzá nem névtelenül elvégeztetett munkával, hanem olyasmivel, amelynél súlya van minden hozzájárulásuknak. Egy szeminárium esetén, például a közös platformot szerkesztve, megtanulhatnak együttmüködni, segíthetik, inspirálhatják egymást. Közben pedig mind a tanár, mind a diák folyamatosan (át)láthatja a másik munkáját, módszereit.

Végső soron a FactGrid használata átjárást, élő kapcsolatot teremt a Wikidata és hosszabb távon a Wikipédia felé. A platformon keresztül megismerkedni a Wikidatával a kutatók számára sem csak közszolgálat: amellett, hogy könnyen áttölthetjük a Wikidata számára releváns adatokat, az oldal többmilliós, tízezrek által karbantartott állományából és adatmodelljéből szilárd alapot generálhatunk kutatásunknak.

University," ACME: An International fournal for Critical Geographies 14 (2015): 1235-1259, https: ://www.acme-journal.org/index.php/acme/article/view/1058.

22 Hannes Werthner et al., „Vienna Manifesto on Digital Humanism,” hozzáférés: 2020.06.12, https : ://www.informatik.tuwien.ac.at/dighum/index.php.

23 John Perry Barlow, „Cyberspace Függetlenségi Nyilatkozat,” Replika 26 (1997): 165-166, http://r eplika.hu/system/files/archivum/replika_26_14_barlow.pdf.

24 Érdemes viszont feltenni magunknak a kérdést: ki szerkesztheti a Wikipédiát?

25 Matthew A. Vetter, Zachary J. McDowell and Mahala Stewart, „From Opportunities to Outcomes: The Wikipedia-Based Writing Assignment," Computers and Composition 52 (2019): 53-64, https: ://doi:10.1016/j.compcom.2019.01.008.

26 Corrado Petrucco, „Wikipedia in University Courses: Teaching Practices and Educational Benefits,” Research on Education and Media 10, 2 (2018): 10-16, https://doi.org/10.1515/rem-2018-0010 . 


\section{Hozzáférés}

Érthető tehát, miért gyümölcsöző a platform használata a kutatói közösségek számára. A FactGrid a kutatási innováció mellett talán akkor nyújthatja a legtöbbet, ha elősegíti az akadémiai világ mélyebb önreflexióját, amely túlmutat a hozzáférés kérdéskörén. Bár még ma is távolinak tűnhet a tudományos közösséget átható, a szakmai publikációkon túlmutató nyílt hozzáférés-szemlélet, fel kell tennünk már most a kérdést: mennyit ér a hozzáférés valójában, ha a szélesebb közönség, sőt talán a kutatók jelentős része sem tud az adott szöveg létezéséről ? Horváth Iván 1999-ben rendkívüli kiállítást rendezett, ahol elveszett magyar honlapok példájával figyelmeztetett az internetes szövegek tárolásának problematikájára. ${ }^{27}$ Külön kiállítást érne viszont az a számtalan, amúgy remek tudományos honlap, virtuális galéria, oktatási és ismeretterjesztő anyag, amely ma is elérhető, de a kommunikáció hiánya miatt csak szűkebb közönség tud a létezéséről, talán még a szakmában sem mindenki, akinek hasznára válhatna. ${ }^{28}$ Ebben nemzetközi szinten sem maradunk el. ${ }^{29} \mathrm{Az}$ archiválás önmagában nem a használatot biztosítja, csak annyit, hogy a szúk kutatói közösség időről időre újra felfedezheti majd ezeket a szövegeket mint történelmi „tárgyakat”. Tudománykommunikáció, tájékoztatás nélkül ugyanis nem válnak a közös tudás részévé; sarkosan fogalmazva: amiről nem tud a közönség, az gyakorlatilag nem is létezik. ${ }^{30} \mathrm{Az}$ obskúrus, elfelejtett honlapok és kutatási projektek nem csak elmulasztott lehetőségek: a közpénzből létrehozott tudás kommunikációja, a megosztás a kutatók alapvető feladata, nemcsak az egyetem falain belül, hanem azon kívül is. Végső soron a tudomány mint társadalmi intézmény nem a belső buborékok felfújogatását szolgálja, hanem hídépítést az azon kívül eső közönséghez: saját határainak eltörlését. A FactGrid használata pedig egy lépést jelenthet ebbe az irányba.

\section{FactGrid: Database for Historians}

FactGrid is an open data-based community database for historians. The platform, running on the easy-to-edit Wikibase, provides research projects a shared database where they can store and analyse structured data. The linked data remains editable in the long-term, we can run complex

27 Horváth Iván, „Magyar tartalomipar, http://magyar-irodalom.elte.hu/contentware/mag yar/.

28 Néhány kiragadott példa a sok közül: „Írónők a hálón 1880-1945,” http://ironok.elte.hu/; „A budai vár," https://budavar .btk.mta.hu/; „József Attila összes műve, http://jozsefatt ila.elte.hu/; „A magyar nyelv finnugor alapjai, http://finnugor .elte.hu/index .php?q= =sztika; „Hálózati tankönyvek, szöveggyüjtemények,” http://magyar-irodalom.elte.hu/g epesk/tk.html; „Tabán térképes képarchívuma, https://web.archive.org/web/201108290 00913/http://atlasz.tabanmuzeum.hu/; Hadas Miklós, „Férfikutatások: Szöveggyüjtemény,” http://publikaciok.lib.uni-corvinus.hu/publikus/643014.pdf, hozzáférés 2020.06.12.

29 „Rombase," http://rombase.uni-graz.at/; Online Encyclopedia of Mass Violence, https://w ww.sciencespo.fr/ceri/en/ouvrage/oemv; Lexicon of Scholarly Editing, https://lexiconse . uantwerpen. be/; Encyclopedia of Mediterranean Humanism, https : / www . encyclopedie-hu manisme.com/; Compendium heroicum, https://www. compendium-heroicum.de/, hozzáférés 2020.06.12.

30 Nehezítő tényező, hogy nincs még központi gyűjtőhelye sem a hasonló oldalaknak. 
queries and visualise the data on map or timeline. In my article, besides introducing the platform, I will try to unpack the ways in which the initiative might enrich historical research in Hungary.

Keywords:

database, FactGrid, Wikibase, structured data, linked open data, history 